\title{
Impact of Manufacturing Industry Performance on Economic Growth of Bosnia and Herzegovina in the pre-COVID-19 Period
}

\author{
Ermin Cero \& Mirza Mustafić \\ International Burch University, Sarajevo, BOSNIA AND HERZEGOVINA \\ Faculty of Economics and Social Sciences
}

Received: 2 September 2021 • Accepted: 1 December 2021 - Published Online: 15 December 2021

\begin{abstract}
In this research, our primary goal is to examine the impact of specific performance of the manufacturing industry on the economic development of Bosnia and Herzegovina. In view of the above, we examine the factors that are considered relevant and that have an impact on economic development, namely the gross domestic product of Bosnia and Herzegovina. Some specific performance of the industry can be reflected through the number of companies, the number of employees in the industry, the amount of exports, as well as investments within the manufacturing industry. The analysis is based on the collected quantitative data published in bulletins, releases and publications of statistical organizations in Bosnia and Herzegovina for the manufacturing industry over a period of five years (2015-2019). In accordance with the mentioned topic, a research model with essential variables, four independent variables (number of companies, number of employees, volume of exports within the industry) and one dependent variable (gross domestic product) were developed. This research will give us the results as well as insight into the specific performance of the processing industry that affects one of the most important indicators of economic development, that is, the gross domestic product of Bosnia and Herzegovina. The results that will emerge from this research will serve as a good basis for further research that could treat this topic with somewhat more identified variables. Also, it is expected that the results of this research will be useful to economic policy makers in Bosnia and Herzegovina, potential investors in some sectors of the manufacturing industry, but also educational institutions as generators of adequate staff.
\end{abstract}

Keywords: manufacturing industry, number of employees, number of enterprises, exports, gross domestic product, manufacturing industry.

\section{Introduction}

In addition to numerous economic activities and sectors in Bosnia and Herzegovina, within the industry, the manufacturing industry occupies a very important place. It consists of a number of economically important sectors, some of which are the production of food products, the production of tobacco products, clothing, furniture, chemicals, furniture and many others. That the manufacturing industry is extremely important is also shown by the allegations of the official institutions of Bosnia and Herzegovina that the manufacturing industry accounts for about $11 \%$ of the country's GDP, about $20 \%$ of total employment and almost $90 \%$ of BiH. export of goods (Directorate for Economic Planning of $\mathrm{BiH}, 2016$ ). The manufacturing industry thus forms one of

(C) Authors. Terms and conditions of Creative Commons Attribution 4.0 International (CC BY 4.0) apply. Correspondence: Ermin Cero, International Burch University, Faculty of Economics and Social Sciences, Sarajevo, BOSNIA AND HERZEGOVINA. E-mail: ermin.cero@ibu.edu.ba. 
E. Cero \& M. Mustafić - Impact of Manufacturing Industry Performance on Economic Growth ...

the main economic sectors in Bosnia and Herzegovina (Foreign Trade Chamber of BiH, 2013). In view of the above, there is a significant reason to examine the impact of manufacturing performance on the main macroeconomic indicator, i.e., gross domestic product. One of the fundamental goals of every country is economic development. Economic development represents the success of an economy. It is a complex economic process by which a country gradually gets rid of economic underdevelopment and poverty, reaching ever higher levels of development. Thus, it consists of economic growth and changes in the economic structure (Devetaković, Jovanović \& Rikalović, 2011). States strive to achieve the highest possible gross domestic product, which is an aggregate that shows the monetary value of total goods and services during one year (Ristić, Komazec \& Ristić, 2016). Industrial production is considered an important prerequisite for the economic development of almost every country (Obadić, 2001). It follows from the above that there is a need to identify the specific performance of the industry, in this case the manufacturing industry that has an impact on the economic development of the country. Analyzing these impacts is of great importance for the creation of both industrial policy and the creation of state economic policy. This study examines the impact of specific performance of the manufacturing industry and its factors on the economic development of the state of Bosnia and Herzegovina through gross domestic product, before the coronavirus-induced pandemic, for the period from 2015 to 2019. The main objectives of this research are:

- Examine the impact of specific performance of the manufacturing industry on the gross domestic product of Bosnia and Herzegovina.

- Examine the relationship between the number of enterprises in the manufacturing industry and the gross domestic product of Bosnia and Herzegovina.

- Investigate the relationship between the number of employees in the manufacturing industry and the gross domestic product of Bosnia and Herzegovina.

- Establish a link between the exports of the manufacturing industry and the gross domestic product of Bosnia and Herzegovina.

- Examine the relationship between investments in the manufacturing industry and the gross domestic product of Bosnia and Herzegovina.

SPSS Statistics 20.0 software will be used for analysis purposes. The software will be used to perform quantitative analysis (regression analysis, correlation, multiple regression). Also, elements of descriptive statistics will be applied, as well as the comparison method. Secondary data for selected variables will be taken from official institutions for data collection, analysis and dissemination in Bosnia and Herzegovina, primarily from the Agency for Statistics of Bosnia and Herzegovina. In its publications, the Agency for Statistics of Bosnia and Herzegovina includes data related to the manufacturing industry, as well as data on gross domestic product. The time period that will be included in the analysis is a period of five years, from 2015 to 2019.

\section{Literature review}

In modern conditions, the purpose of every economy and society is to fully satisfy the overall material, social, cultural and other needs of the entire population. In order to achieve this in the most successful way possible, it is necessary to constantly improve all forms of living and working conditions for people, in order to improve the overall economic development. This would increase per capita income and increase living standards. This can be achieved through better development of the primary, secondary and tertiary sectors. That is why the purpose of every modern and contemporary country is to maximize economic growth. It is a process in which the 
aim is to achieve the highest possible growth rate of production. This significantly contributes to the achievement of other goals and tasks of development. Among these goals it is especially important to emphasize: increasing employment, influencing the growth of labor productivity and capital efficiency, development of economic relations with foreign countries, meeting all forms of consumption, structural harmonization of the economy, solving regional development issues, achieving political stability and international reputation. In this way, employment opportunities are expanding not only in industry, but also through multiplier effects in many other sectors. Industry is the main branch and driver of the whole economy. Therefore, through economic policy measures, especially industrial policy, great efforts are made to bring the industry of a country as close as possible to the development, and thus growth in terms of positive trends that would result in positive trends in GDP and overall welfare. We can define industry as a set of activities whose main goal is the production of goods and their sale. The development of industry had a great impact on the growth of living standards and well-being, which further encouraged the process of industrialization. Throughout history until today, the industry has undergone numerous processes (transition, privatization) and today in the $21^{\text {st }}$ century it is going through technological development that has affected the economy of each country. Numerous experts and scientists have conducted research on the impact of industry or the manufacturing industry on economic development. By economic development they meant improvements of various economic aggregates, such as gross domestic product, national income and the like. Industrial development has played a very important role in the economic development of countries such as China, Korea, Taiwan, Indonesia. Growth in the industrial sector is key to sustainable long-term economic growth and poverty reduction (Kniivilä, 2007). One of the papers states that industry has a significant impact on all dimensions and sustainable development - economic, social, environmental and institutional. When it comes to the European Union, somewhere around 24\% of GDP is generated by industry, it also employs about 50 million people (Behun, Gavurová, Tkacova \& Kotaskova, 2018). Within the industry, the manufacturing industry is considered to be an extremely important component. According to official information (World Bank, 2021), in 2004 the manufacturing industry accounted for $17.2 \%$ of world GDP, while in 2018 it accounted for about $15.2 \%$ of world GDP. In a paper related to the UK, it was pointed out that the manufacturing industry makes great contributions to the national economy thanks to certain sectors that add value to the gross domestic product. Industrial exports increased, which in turn affected economic development (Dean Group, 2018). One study also confirmed that the growth of production within an industry is the foundation for economic development, especially in middleincome countries (Nelson, Reis \& Araújoc, 2016). The research (Fagerberg \& Verspagen, 1999) did a regression of the real GDP growth rate and the growth rate of the manufacturing industry. Fegerberg and Verspagen realized that production was a typical engine of growth in developing countries in East Asia and Latin America. They found that there was no significant effect on output in advanced economies. In another paper (Fagerberg \& Verspagen, 2002), they examined the impact of the share in service output and economic growth in three periods, 1966-1972, 1973-1983, 1984-1995, for a sample of 76 countries. They found that the effects were much more positive before 1973 than after. They found that even after 1973, with the development of information technology, productivity increased, especially in the 1990s. According to a limited sample of Asian and Latin American developing countries, growth was examined (Szirmai, 2012). The focus was on high intensity, production growth and labor productivity. In this way, it confirms the hypothesis regarding the driver of growth. Rodrik (2009) regresses GDP growth rates to the shares of industry in GDP, for a period of five years. He finds a significant positive relationship and interprets the growth of developing countries in the post-war period through the argument of structural change. He concludes that in fact modern industrial activity acts as an engine of growth. Thus, he states that structural transformation is one of the explanations for accelerated growth and development. In one econometric analysis for India, (Chakravarty \& Mitra, 2009) reveal that production is clearly one of the determinants of overall growth but also find that services are becoming increasingly important for production growth. In a domestic analysis, Hadžić (2019) 
states that the manufacturing industry in Bosnia and Herzegovina is one of the most important pillars of the economic system. According to the presented data, the manufacturing industry employed about 142,580 workers at the end of 2017, which was an increase compared to 2015. The above data actually shows that about $18.9 \%$ (2017) of the total number of employees work in this industry. The number of companies has also increased and especially in smaller companies, companies with fewer workers. The author also states that this industry can become an even more important factor for achieving faster economic development (Hadžić, 2019). In a review article (Obadić, 2001), the author states that the manufacturing industry derives its importance from several elements. First, the productivity of the manufacturing industry is significantly higher than that in traditional agriculture because the products are more diverse and more suitable for exchange, which enables specialization. Industrialization has contributed to greater urbanization and the transition of workers from one sector to another. Industrial development affects the faster development of agriculture and other industries, it also affects the development of infrastructure, technological progress, development of services and which leads to economic development. Furthermore, he believes that the economic development of a country can be observed by observing the movement of national income of individual countries. As a result of the Industrial Revolution in Great Britain, from 1780 to 1860 British per capita income doubled, from 1860 to 1990 it quadrupled. These data only confirm how strong the strong growth in the first eighty years was, but it was only a precursor to the future growth of modern industrialized countries. Authors in a study entitled "Manufacturing as an engine of growth: Which is the best fuel?" they proved that in fact industrialization, higher production is the engine of growth in some regions, while in others it is not. More intensive improvement of industrial production promotes growth through productivity and the share of employment in the manufacturing industry. In the mentioned research, among other things, one of Kaldor's laws was confirmed, that production is the basic engine of growth. They find that intensive rather than extensive industrialization is closely related to GDP (United Nations Industrial Development Organization, 2014). Various studies address some aspects of this topic, however when it comes to a model formed in this way, studies are not available. By systematizing some previous research, it is most often mentioned that industry, as well as the manufacturing industry itself, significantly determines the economic development of the country because they have a stimulating effect on gross domestic product.

\section{Methodology}

All the necessary data to be used in this research relate to size, performance within the manufacturing industry, as well as a key economic indicator in Bosnia and Herzegovina. Data were collected from the database and publications of the umbrella statistical institution in Bosnia and Herzegovina, the Agency for Statistics of Bosnia and Herzegovina. The data of the Agency for Statistics of Bosnia and Herzegovina are relevant given that it is the main carrier, disseminator and coordinator of the official statistics system in Bosnia and Herzegovina. The period covered by this analysis covers a time interval of five years, from 2015 to 2019 for the manufacturing industry and the state of $\mathrm{BiH}$.

In order to explore how the manufacturing industry performance reacts to economic development of Bosnia and Herzegovina, we developed a model in which we used different variables (one dependent and four independent variables) selected on the basis of relevant theory and literature. This research study includes variables that affect the gross domestic product (GDP) in Bosnia and Herzegovina. In order to understand whether GDP can be predicted based on number of companies, employees, export, investments we use multiple regression. Multiple regression is an extension of simple linear regression. It is used when we want to predict the value of a variable based on the value of two or more other variables. The variable we want to predict is called the dependent variable (or sometimes, the outcome, target or criterion variable). The 
variables we are using to predict the value of the dependent variable are called the independent variables (or sometimes, the predictor, explanatory or regressor variables).

\subsection{Hypothesis}

The primary problem investigated in this paper is the impact of industry-specific performance, namely the number of companies, the number of employees in industry, the amount of exports and investments in the manufacturing industry on economic development and gross domestic product of Bosnia and Herzegovina.

Hypothesis \#1:

H1: There is a significant relationship between the number of enterprises in the manufacturing industry and the gross domestic product in Bosnia and Herzegovina.

Hypothesis \#2:

H2: There is a significant relationship between the number of persons employed in the manufacturing industry and the gross domestic product in Bosnia and Herzegovina.

Hypothesis \#3:

H3: There is a significant link between exports within the manufacturing industry and Bosnia and Herzegovina's gross domestic product.

Hypothesis \#4:

$\mathrm{H}_{4}$ : There is a significant link between investments in the manufacturing industry and the gross domestic product of Bosnia and Herzegovina.

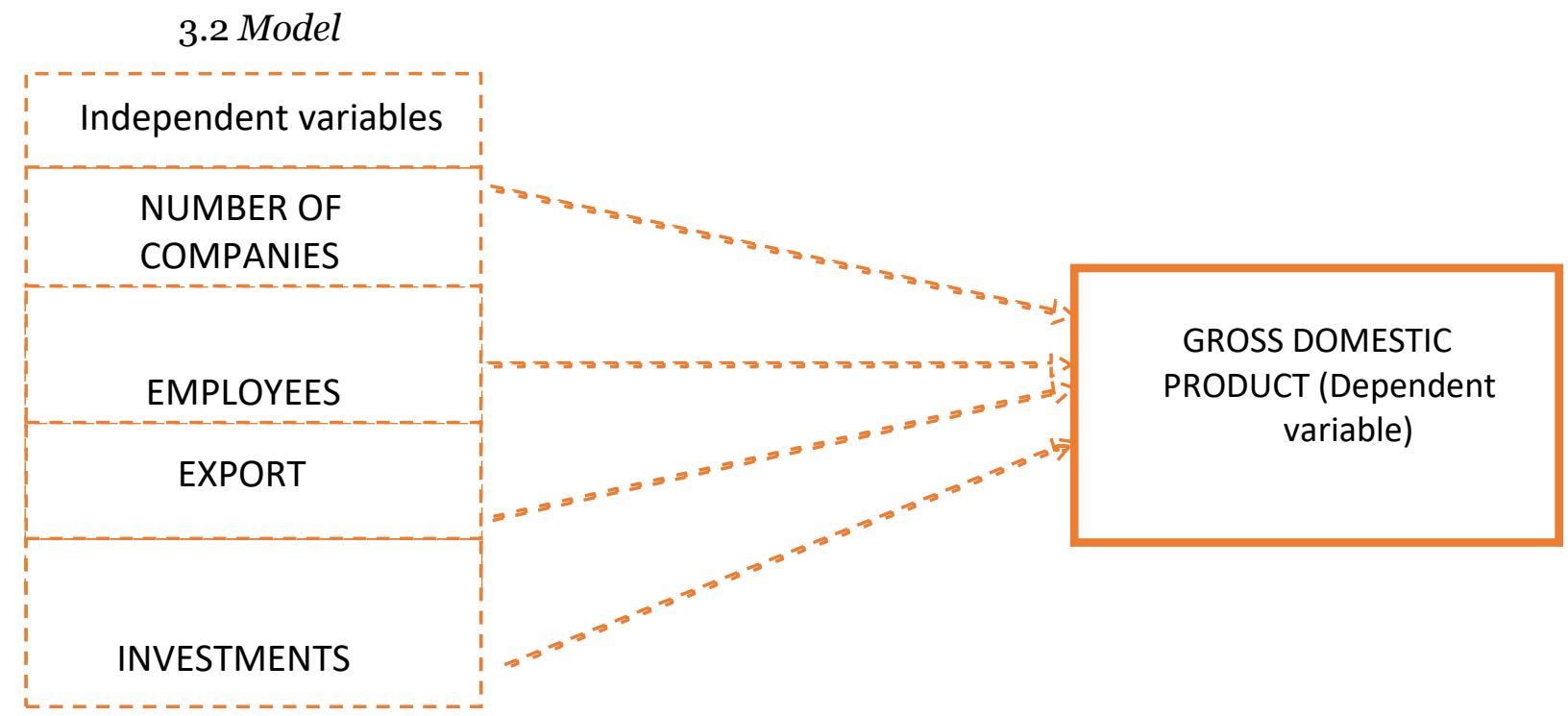

\subsection{Contribution of the study}

The key contribution of this study arises from the application and refinement of the framework for the empirical analysis of the case studies and in order to understand how the interplay between number of companies, employees, export and investments affect GDP. 
E. Cero \& M. Mustafić - Impact of Manufacturing Industry Performance on Economic Growth ...

\section{Results}

As mentioned earlier, the processing industry is one of the most important elements of the economic development of Bosnia and Herzegovina. In previous years, the processing industry has been growing stronger, both in Bosnia and Herzegovina and in the world. In this section, we will discuss several key indicators that will indicate the state of the processing industry in Bosnia and Herzegovina. Data collected for selected variables were taken from official institutions for data collection, analysis and dissemination in Bosnia and Herzegovina, primarily from the Agency for Statistics of Bosnia and Herzegovina. In its publications, the Agency for Statistics of Bosnia and Herzegovina includes data related to the processing industry, as well as data on gross domestic product. The time period we covered when collecting data is the period from 2015 to 2019.

The data of indicators that have been collected and that are of the greatest importance to us are:

(1) Number of companies,

(2) Number of employees,

(3) Exports from the processing industry,

(4)Investments in fixed assets,

(5) Gross domestic product.

Data for the number of enterprises, number of employees, gross domestic product for the manufacturing industry for the years 2015, 2016, 2017, 2018, 2019 were taken from the publications "Bosnia and Herzegovina in numbers". Further, from the publications "National Accounts: Investments "Data related to investments in fixed assets have also been taken over for the previously mentioned years. The number of enterprises includes all legal and natural persons engaged in market production and who are registered in the business register in the population that is the subject of observation. Number of employees is defined as the total number of persons working in the observation unit (including working owners, partners who regularly work in the unit and unpaid family members who regularly work in the unit), as well as persons working outside the unit to which they belong and who pay them (e.g., sales representatives, suppliers). Investments in fixed assets include the acquisition of companies and other organizations to acquire new assets, increase the value or replace existing fixed assets (residential buildings, other buildings and structures, equipment and devices of a more permanent nature, afforestation and erection of long-term plantations, mining and mineral exploration, and software). Acquired fixed assets can be purchased in the country and abroad; procured through financial leasing; can be acquired by barter; received as a capital transfer in kind or produced and retained for own use. All types of investments in new capacities are included, as well as for expansion, reconstruction and modernization of existing ones and replacement of obsolete, worn out or destroyed capacities. Investments in intermediate consumption, regular and current maintenance, repairs, procurement of weapons, acquisition of fixed assets through operating leases, changes in inventories, acquisition of fixed assets for final consumption of households, ownership gains and losses on fixed assets resulting from disasters are not included. Payments for investments in fixed assets represent cash investments during the reporting year, regardless of the time when the construction, production or acquisition of fixed assets was performed (Agency for Statistics of Bosnia and Herzegovina, 2019). The number of enterprises, the number of employees, exports from the manufacturing industry, investments in fixed assets are shown in the table below, Table 1. 
Table 1. Number of companies, number of employees, exports, investments of the processing industry

\begin{tabular}{|c|c|c|c|c|c|}
\hline Prerađivačka ind. & 2015 & 2016 & 2017 & 2018 & 2019 \\
\hline Number of companies & 9,805 & 10,282 & 10,794 & 10,600 & \\
\hline Number of employees & 140,762 & 150,177 & 159,871 & 167,785 & \\
\hline Exports (in thousands of KM) & $8,124,184$ & $8,474,124$ & $9,866,485$ & $10,621,006$ & $10,265,028$ \\
\hline Investments (in ooo KM) & 840,812 & 845,862 & 938,692 & 979,103 & 966,433 \\
\hline
\end{tabular}

Source: Agency for Statistics of Bosnia and Herzegovina; http://www.bhas.ba/ (Retrieved: 22.05.2021)

The number of companies within the processing industry has been increasing since the first year covered. From 2015, when the number of companies is 9,805 people, until 2016, the number increased by 477, when it amounted to 10,282 companies in the manufacturing industry. In 2017, there is another increase when the number of companies increases to 10,794. Unfortunately, the number of companies, for example, decreased in 2018 by 194 companies and amounted to 10,600. The data are also shown in the following chart (Chart 1).

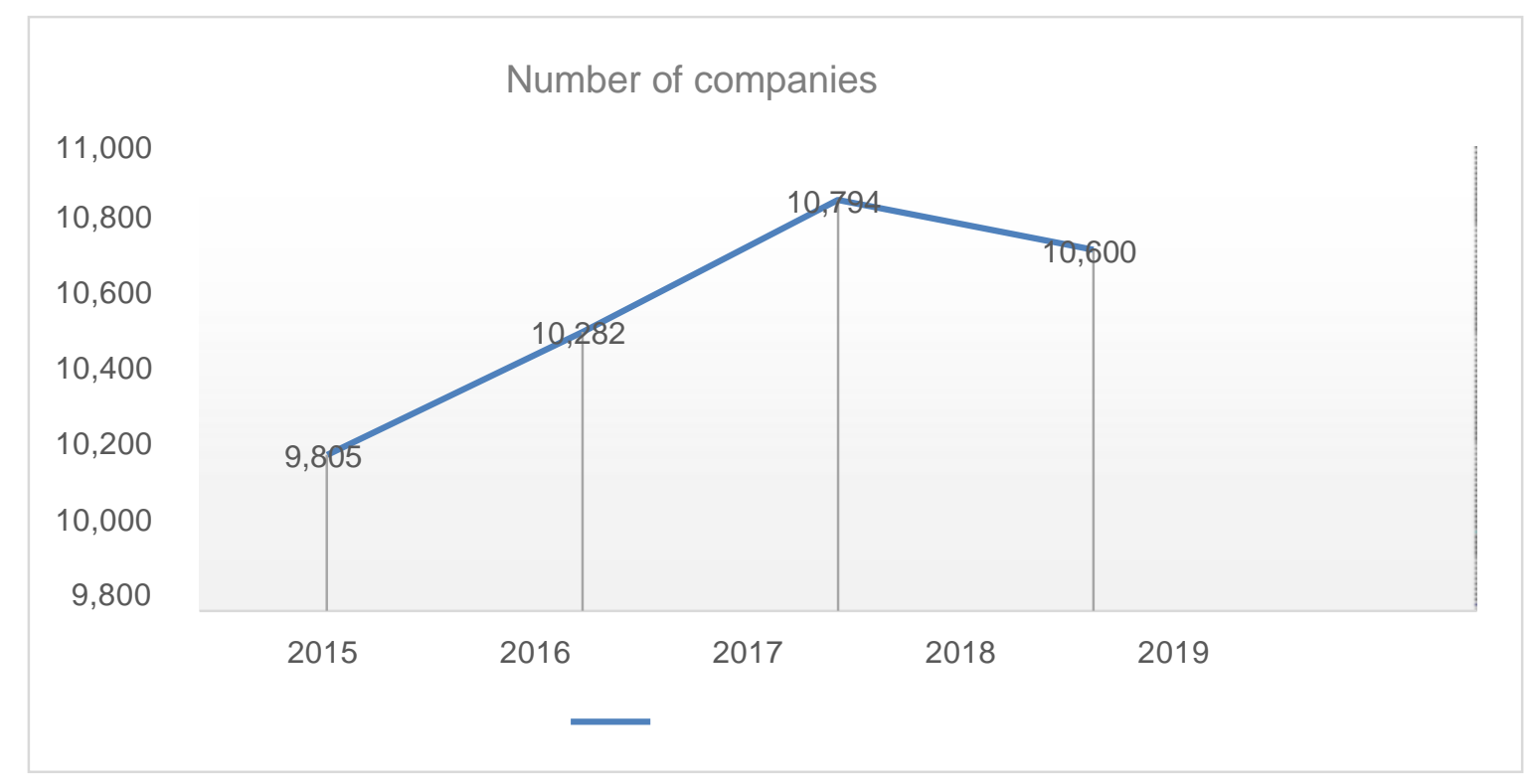

Source: Creation of author based on data from the Agency for Statistics of Bosnia and Herzegovina;

$$
\text { http://www.bhas.ba/ }
$$

Chart 1. Number of companies within the processing industry of $\mathrm{BiH}$

The number of employees is the next indicator shown in the table. Data for the number of employees refer to the time range from 2015 to 2019. In relation to the number of companies, the number of employees has been constantly growing since 2015. In 2015, the number of employees in the manufacturing industry was 140,762. A year later, the number of employees increased to 150,177. In 2017, the number of employees continued to grow and reached 159,971 employees, which is an increase compared to the previous year of 9,694. In 2018, the number of employees was 167,785 . In order to facilitate the perception of this trend of increasing the number of employees, Chart 2 was created, which also shows. 
E. Cero \& M. Mustafić - Impact of Manufacturing Industry Performance on Economic Growth ...

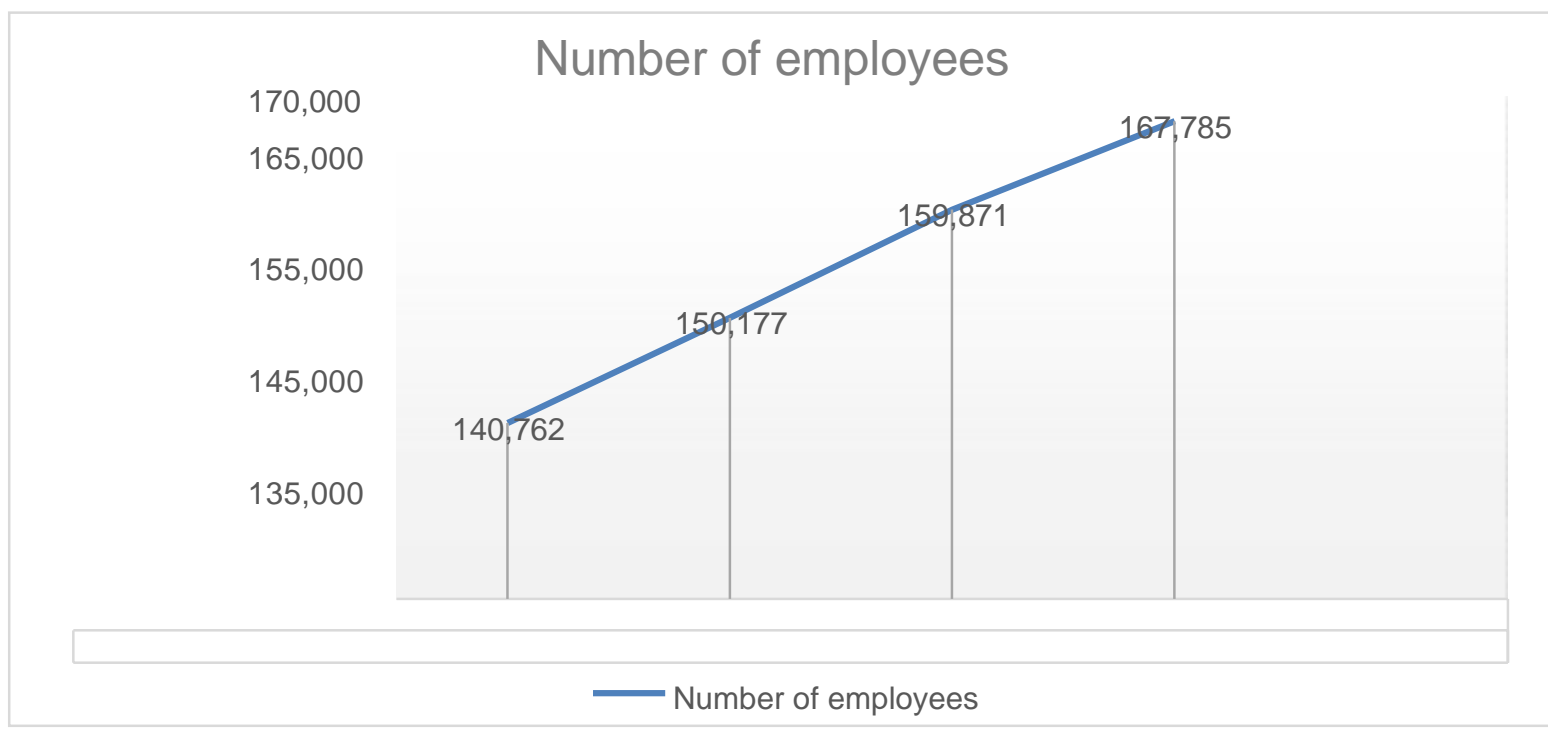

Source: Creation of author based on data from the Agency for Statistics of Bosnia and Herzegovina; http://www.bhas.ba/

Chart 2. Number of employees within the processing industry of BiH

Exports from the manufacturing industry is another item that supports the claim of progress in this activity in BiH. Chart 3 shows the exports that companies in the manufacturing industry have achieved over the years. Exports in 2015 amounted to 8,124,184 thousand KM, in 2016 it further increased to 8,474,124, and in 2017 it amounted to 9,866,485 KM. Exports increased again in 2018, when they reached the value of 10,621,006, after which the decline in exports began in 2019, when it amounted to 10,265,028. The decline in 2019 was caused by the spread of the coronavirus pandemic when many countries, like Bosnia and Herzegovina itself, closed their borders. Therefore, based on the previously presented data, we can say that in parallel with the increase in the number of employees, as well as the increase in the number of companies, the export of companies from the processing industry also increased. This certainly confirms the importance and the very potential of this activity in Bosnia and Herzegovina.

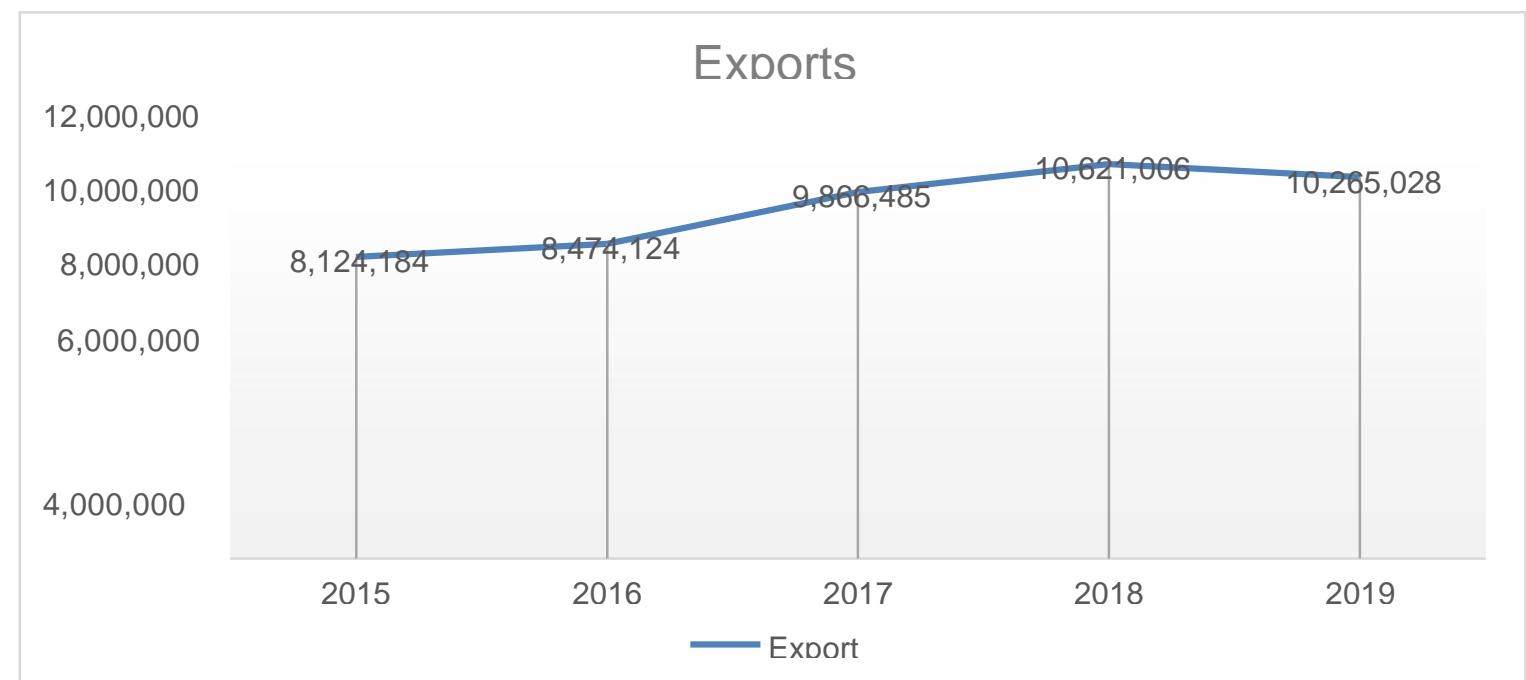

Source: Creation of author based on data from the Agency for Statistics of Bosnia and Herzegovina; http://www.bhas.ba/

Chart 3. Exports realized within the processing industry of BiH 
Chart 4 shows us the investments that increased from 2015 until 2019. In 2015, investments amount to $840,812 \mathrm{KM}$. Next year, the investments will reach the value of 845,862 KM. Furthermore, in 2017, investments increased to the value of 938,692 KM. Companies operating in the manufacturing industry in 2018 also increased their investments to 979,103 KM. Already in 2019, investments are decreasing and then amount to 966,433. More specifically, the presented data refer to payments for investments in fixed assets, according to the activity itself. We mentioned earlier that investments in fixed assets involve the acquisition of companies and others in order to acquire new assets, increase the value or replace existing fixed assets. It is important to note that on average, $71 \%$ of investments are actually from own sources, much less from financial loans, pooled funds, leasing and the like.

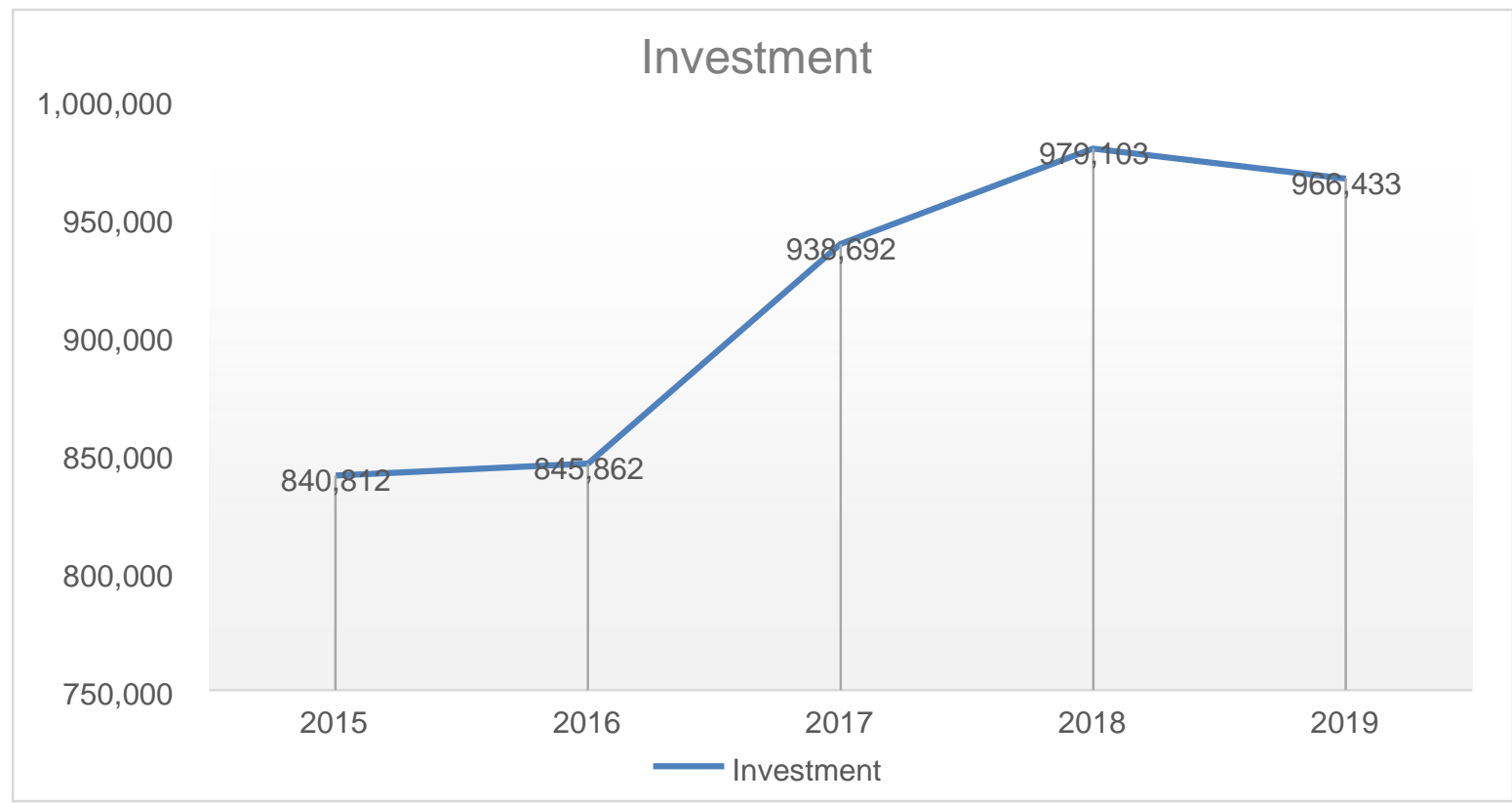

Source: Creation of author based on data from the Agency for Statistics of Bosnia and Herzegovina; http://www.bhas.ba/

Chart 4. Investments in the processing industry of $\mathrm{BiH}$

The manufacturing industry in 2019 also achieved a reduction in production which is important to note. Given the structure of production within the manufacturing industry in Bosnia and Herzegovina, which has a high degree of export orientation and economic trends in the external environment, the decline in production in the manufacturing industry is not surprising. Namely, according to the preliminary data of BHAS for 2019, within the manufacturing industry in Bosnia and Herzegovina, a decrease in production of $5 \%$ compared to the previous year was registered. The key determinant of these trends within the export-oriented manufacturing industry were developments in the international economic environment and major trading partners, as well as problems faced by some companies that represent the backbone of the manufacturing industry in Bosnia and Herzegovina. Thus, according to EUROSTAT data for 2019, there was a decrease in the physical volume of industrial production in the EU28 by 1\%. Observed by countries, the most significant reductions in the physical volume of production were recorded in Germany $4.4 \%$, Italy 1.4\%, Turkey $0.8 \%$, Croatia $0.3 \%$, while in Serbia stagnation was recorded 0.3\% (Directorate for Economic BiH planning, 2019). Table 2 shows the data related to the gross domestic product of Bosnia and Herzegovina for the period from 2015 to 2019. GDP data are of great importance to us given the joint analysis of previous data with GDP data. Two indicators of gross domestic product are shown in the table below, gross domestic product in absolute amount as well as gross domestic product per capita. In 2015, the gross domestic product of Bosnia and 
E. Cero \& M. Mustafić - Impact of Manufacturing Industry Performance on Economic Growth ...

Herzegovina amounted to 28,589 mil. KM, in the following year 2016 amounted to 29,904. Gross domestic product increased in the following years as well, so in 2017 it amounted to 31,376 KM, in 2018 to 34,444 and in 35,296 mil. KM. For us, it is perhaps a more important indicator that shows the gross domestic product per capita, more precisely the gross domestic product per capita.

Table 2. Gross domestic product of $\mathrm{BiH}$

\begin{tabular}{|l|l|c|c|rc|}
\hline & $\mathbf{2 0 1 5}$ & $\mathbf{2 0 1 6}$ & $\mathbf{2 0 1 7}$ & $\mathbf{2 0 1 8}$ & $\mathbf{2 0 1 9}$ \\
\hline GDP of BiH, mil. KM & 28,589 & 29,904 & 31,376 & 33,444 & 35,296 \\
\hline GDP per capita, KM & 8,127 & 8,517 & 8,954 & 9,566 & 10,128 \\
\hline
\end{tabular}

Source: Creation of author based on data from the Agency for Statistics of Bosnia and Herzegovina; http://www.bhas.ba/ (Retrieved: 22.05.2021.)

Gross domestic product per capita in 2015 amounted to 8,127 KM, but in 2016 it amounted to $8,517 \mathrm{KM}$. Further in 2017 , the gross domestic product per capita amounts to 8,954 $\mathrm{KM}$, in 2018 it will increase to as much as 9,566 KM. Gross domestic product increased in 2019 when it amounted to $10,128 \mathrm{KM}$. Chart 5 shows the gross domestic product of Bosnia and Herzegovina per capita in parallel with the gross domestic product expressed in absolute terms from 2015 to 2019.

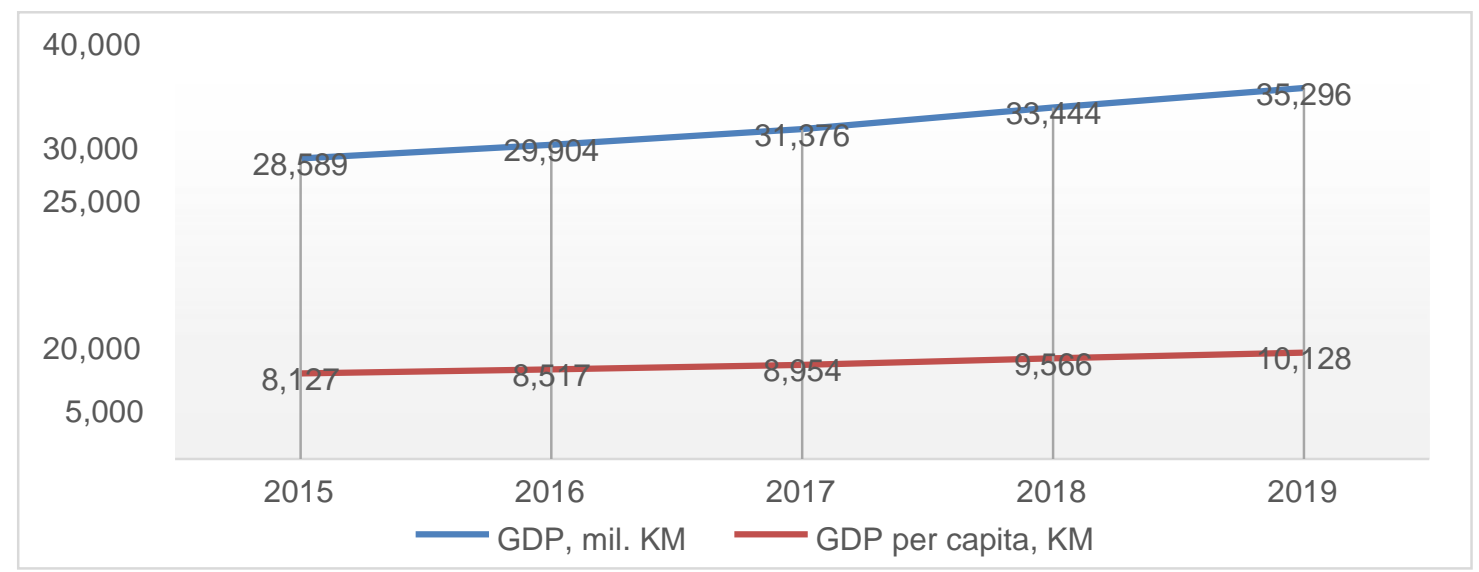

Source: Creation of author based on data from the Agency for Statistics of Bosnia and Herzegovina; http://www.bhas.ba/

Chart 5. GDP of Bosnia and Herzegovina

\subsection{Hypothesis testing}

The table 3 consists of 4 values. The value of the multiple correlation coefficient is 1,000. This coefficient serves to determine the quality of the prediction of the dependent variable, in this case GDP. A value of 1,000 represents a good level of prediction. The table also presents the decision coefficient, R Square $=1,000$, whose value represents $0 \%$ of the variability of the dependent variable, which cannot be explained by independent variables, so the strength of the connection is weak.

Table 3. Model summary

\begin{tabular}{|l|l|l|l|l|}
\hline Model & R & R Square & Adjusted R Square & Error of the Estimate \\
\hline 1 & $1.000^{\mathrm{a}}$ & 1.000 & & \\
\hline
\end{tabular}

Predictors: (Constant), Investments (thousands of convertible marks), Number of companies, Number of employees (Source: Author's own work) 
The F-value in the ANOVA table, shown below, tests whether the regression model is good for these values. Based on the Table 4, it can be noticed that the regression model is not good for analysis because $\mathrm{F}$ values and significance were not measured, for this reason correlation analysis was used in further analysis.

Table 4. Anova

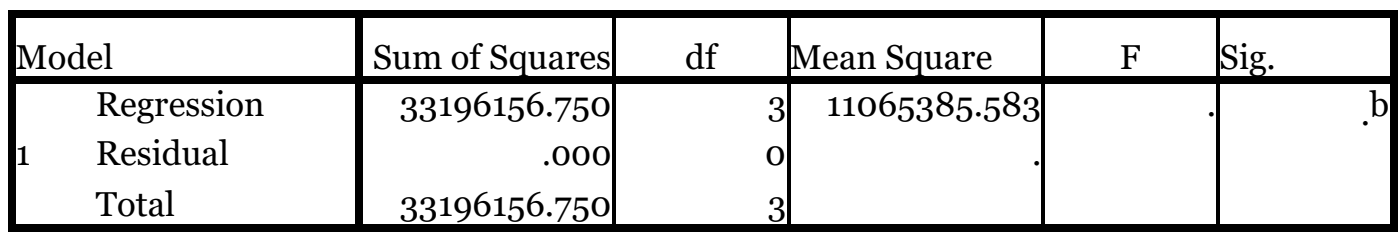

a. Dependent Variable: Gross Domestic Product (millions of convertible marks)

Predictors: (Constant), Investments (thousands of convertible marks), Number of companies, Number of employees (Source: Authors' own work)

The following Table 5 shows the effect of GDP on the number of companies, employees, exports, investments. From the table 5 we will note that there is no relationship between the number of companies and GDP because Sig> 0.05 and is 0.1. However, when it comes to the number of employees, exports and investments, the significance is Sig <0.05 and amounts to 0.02 for the number of employees, 0.03 for exports and 0.05 for investments, and since the correlation coefficient is positive, it means that about a strong positive correlation. Based on that, it can be concluded that if the number of employees, exports and investments increases, then there is an increase in GDP.

Table 5. Variables' correlations

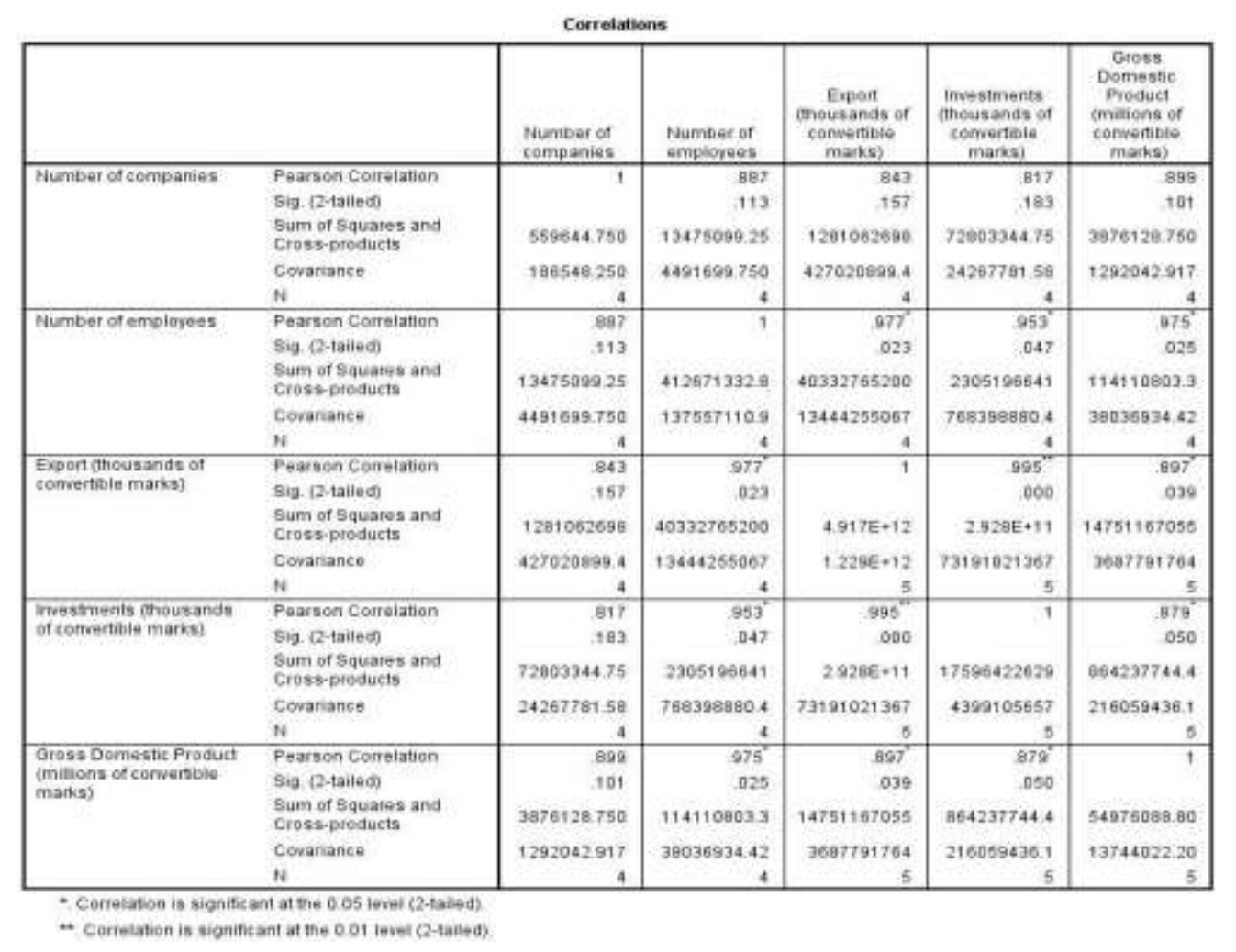

Source: Authors' own work

Based on the correlation analysis, we can conclude that there is a significant relationship between the number of persons employed in the manufacturing industry, exports 
E. Cero \& M. Mustafić - Impact of Manufacturing Industry Performance on Economic Growth ...

within the manufacturing industry and a significant link between investments in the manufacturing industry and the gross domestic product of Bosnia and Herzegovina.

\section{Data analysis and discussion}

Given the data collected and presented in the previous section, we can draw a number of conclusions about the impact of specific performance on the economic development of Bosnia and Herzegovina. The number of companies that increased from 2015 to 2018 was accompanied by an increase in the gross domestic product of Bosnia and Herzegovina, and based on which we can conclude that a larger number of companies managed to influence the increase in gross domestic product. Although, the increase in gross domestic product can certainly be caused by other reasons as well. The number of employees in the manufacturing industry has increased drastically from year to year, with an increase in the gross domestic product of Bosnia and Herzegovina. It is clear that a larger number of companies also employed a larger number of employees because there was a greater need for random power due to the increase in demand. The same results were confirmed by Hadžić (2019). In a domestic analysis, Hadžić (2019) states that the manufacturing industry in Bosnia and Herzegovina is one of the most important pillars of the economic system. According to the presented data, the manufacturing industry employed about 142,580 workers at the end of 2017, which was an increase compared to 2015. The above data actually shows that about $18.9 \%$ (2017) of the total number of employees work in this industry. The number of companies has also increased and especially in smaller companies, companies with fewer workers. The author also states that this industry can become an even more important factor for achieving faster economic development (Hadžić, 2019). One of the papers states that industry has a significant impact on all dimensions and sustainable development - economic, social, environmental and institutional. When it comes to the European Union, somewhere around 24\% of GDP is generated by industry, it also employs about 50 million people (Behun, Gavurová, Tkacova \& Kotaskova, 2018). Undoubtedly, such two increases also led to an increase in gross domestic product. Another indicator that confirms the previous impact is exports from the processing industry. Companies within the manufacturing industry recorded an upward trend, while in 2018 there was a decline, during which time GDP was in constant growth so we cannot confirm here that the number of companies is related to GDP. The same was confirmed by correlation analysis. Exports increased from 2015 to 2018, which certainly contributed to the increase in gross domestic product. Other authors came to similar results. In a paper related to the UK, it was pointed out that the manufacturing industry makes great contributions to the national economy thanks to certain sectors that add value to the gross domestic product. Industrial exports increased, which in turn affected economic development (Dean Group, 2018). One study also confirmed that the growth of production within an industry is the foundation for economic development, especially in middle-income countries (Nelson, Reis, \& Araújoc, 2016). The research (Fagerberg \& Verspagen, 1999) did a regression of the real GDP growth rate and the growth rate of the manufacturing industry. Fegerberg and Verspagen realized that production was a typical engine of growth in developing countries in East Asia and Latin America. They found that there was no significant effect on output in advanced economies.

Investments in fixed assets are also an indicator that has been increasing since the first observed year. By comparing the graphs and comparing the results of the correlation analysis, we can conclude that investments have a certain impact on increasing the gross domestic product of the state. From the above, summarizing the partial conclusions, we can conclude that specific performance in the form of number of companies, number of employees, exports from the manufacturing industry, investment in fixed assets have a significant impact on the economic development of Bosnia and Herzegovina in the period before COVID. along with the increase in gross domestic product, which in our case means economic development. 


\section{Conclusion}

One of the most important indicators of a country's economic development is gross domestic product (GDP), which consists of four basic components: personal consumption (C), investment consumption (I), government consumption (G) and net exports (NX). In order for this indicator to be as good as possible, transparent conduct of macroeconomic policy by policy makers is needed. The aim of this paper was to show how the impact of certain indicators will affect the growth of real GDP of Bosnia and Herzegovina. Therefore, arbitrary variables (number of companies, number of employees, exports and investments) in the five-year period (2015 to 2019) were selected. In our model, real GDP was a dependent variable and we confirmed the following analysis. The number of employees in the observed period has a significant impact on real GDP growth, specifically: a larger number of companies employed a larger number of employees because there was a greater need for random power due to increased demand. Undoubtedly, such two increases also led to an increase in gross domestic product. Another independent variable, the number of companies in 2018, showed a negative impact on real GDP, i.e., their reduction did not affect the decline in GDP because GDP in 2018 reached its maximum growth. Indicators in the time before the COVID-19 virus pandemic were also taken into analysis. It can be seen from the model that all variables are in equilibrium in certain periods and in the last years of the observed period they are growing. In order to maintain their growth at a sustainable level, prudent action by macroeconomic policy makers is needed, primarily through monetary and fiscal policy. A study of the literature for this analysis revealed different observations of the variables used in this analysis. However, based on this analysis, the same or similar results were obtained as in previous research, thus confirming the theoretical background and significance of the model. That is, we concluded that there is a long-run linear relationship between the observed variables. With the obtained results of the conducted analysis, we cannot reject the hypotheses that we set in the introductory chapter of this paper. Looking at the current situation in the Bosnian economy and what analysts are saying to the public, we can see the economic recovery from the effects of the global economic crisis; which affected a not so significant increase in the value of the observed variables. It is considered that in the further recovery period it is important to focus on increasing investment as one of the main components of GDP because only an increase in investment can have a significant long-term effect on GDP growth, which was confirmed by the analysis. Thoughtful action of policy makers would reduce the resulting gap in the value of the observed variables, but would also reduce the economic lag, primarily for EU member states. However, among the holders of macroeconomic policy, the stumbling block is still the transparency of policy action, ie the choice of which policy to pursue in order to preserve the stability of the processing industry of Bosnia and Herzegovina.

\section{Acknowledgements}

This research did not receive any specific grant from funding agencies in the public commercial, or not-for-profit sectors.

The authors declare no competing interests. 
E. Cero \& M. Mustafić - Impact of Manufacturing Industry Performance on Economic Growth ...

\section{References}

Agencija za statistiku Bosne i Hercegovine (2019). Bosna i Hercegovina u brojevima. Sarajevo: Agencija za statistiku Bosne i Hercegovine.

Agency for Statistics of Bosnia and Herzegovina (2020). Industrial production of Bosnia and Herzegovina - 2019. Sarajevo: Agency for Statistics of Bosnia and Herzegovina.

Augustyn, A. (2021). Industrial Revolution. Britannica. Retrieved 15 February 2021 from https://www.britannica.com/event/Industrial-Revolution.

Beg, M. (2018). Održivi ekonomski razvoj - prepreke i rješenja. Zbornik radova znanstvenog skupa: Modeli razvoja hrvatskog gospodarstva, 371-394.

Behun, M., Gavurová, B., Tkacova, A., \& Kotaskova, A. (2018). The impact of the manufacturing industry on the economic cycle of European union countries. Journal of Competitiveness, 1O(1), 23-39.

Blanchard, O., \& Johnson, D. (2013). Macroeconomics - Sixth edition. Pearson.

Celebic, N., Muzur, A., \& Cero, E. (2020). Regional determinants of export competitiveness in manufacturing industry. EcoForum, 9(3(23)).

Chakravarty, S., \& Mitra, A. (2009). Is industry still the engine of growth? An econometric study of the organized sector employment in India. Journal of Policy Modeling, 22-35.

Dean Group (2018). Why-is-manufacturing-important-to-the-economy. Dean Group. Retrieved 13 March 2021, from Dean Group: https://www.deangroup-int.co.uk/why-is-manufacturing-importantto-the-economy/.

Devetaković, S., Gavrilović, B., \& Rikalović, G. (2011). Nacionalna ekonomija. Beograd: Centar za izdavačku djelatnost Ekonomskog fakulteta u Beogradu.

Direkcija za ekonomsko planiranje BiH (2019). Godišnji izvještaj za 2019. godinu. Tuzla: Direkcija za ekonomsko planiranje $\mathrm{BiH}$.

Enciklopedija. Retrieved 18. 032021 from https://www.enciklopedija.hr/.

Enciklopedija. Retrieved 21.04.2021 from https://www.enciklopedija.hr/natuknica.aspx?id=63873.

Enciklopedija. Retrieved 24. 04 2021. from https://www.enciklopedija.hr/natuknica.aspx?id=63545.

Fagerberg, J., \& Verspagen, B. (1999). Modern capitalism in the 1970s and 1980s. In Growth, employment and inflation. Essays in honour of John Cornwall (p. 1999). London: Macmillan Press.

Fagerberg, J., \& Verspagen, B. (2002). Technology-gaps, innovation-diffusion and transformation: An evolutionary interpretation. Research Policy, 31, 1291-1304. Fandom. Retrieved 17 March 2021, from https://enciklopedija.fandom.com/bs/wiki/Industrija.

Hadžić, F. (2019). Može li prerađivačka industrija u BiH biti generator ekonomskog rasta. ResearchGate. Retrieved 13 February 2021, from https://www.researchgate.net/publication/335892349 Moze li preradivacka industrija u _ BiH_biti_generator_ekonomskog_rasta.

Hasić, D. (2014). Annual review of labour relations and social dialogue in South East Europe: Bosnia and Herzegovina. Beograd: Friedrich-Ebert-Stiftung.

Herman, E. (2015). The importance of the manufacturing sector in the Romanian Economy. In $9^{\text {th }}$ International Conference Interdisciplinarity in Engineering (pp. 976-983). Tirgu- Mures: Petru Maior University of Tirgu-Mures.

History (2021). Industrial revolution. Retrieved 16 February 2021, from https://www.history.com/topics/industrial-revolution/industrial-revolution. 
Hodzić, K., \& Mahmutović, H. (2017). Osnove ekonomije. Tuzla: Visoka škola za finansije i računovodovstvo.

Impoff (2021). Importance of industry. Retrieved 17 March 2021, from https://impoff.com/importance-ofindustry/.

Karaman Aksentijević, N. (2011). Industrija, u Čavrak V. Gospodarstvo Hrvatske, Grafo Idea, Zagreb, 148.

Kniivilä, M. (2007). Industrial development and economic growth: Implications for poverty reduction and income inequality. ResearchGate, 295-332.

Kovačević, Z., Beg, M., i Sekur, T. (2016). Gospodarsko značenje industrïe u Obadić A. i J. Tica. Gospodarstvo Hrvatske, Zagreb, Sveučilišna tiskara d.o.o., 370.

Komazec Bogavac, M., Ristić, Ž., \& Ristić, K. (2012). Ekonomska analiza. Beograd: EtnoStil.

Mahmutović, H., Hodžić, K., \& Čejvanović, F. (2017). Ekonomska politika otvorene ekonomije. Zenica: Univerzitet u Zenici Ekonomski fakultet.

Mate, B. (2004). Makroekonomija - četrnaesto izdanje. Zagreb: MATE.

Nelson, M., Reis, C. F., \& Araújoc, E. C. (2016). Manufacturing and economic development: The actuality of Structural Change and Economic Dynamics, 75-89.

Nikolić, G. (2017). Industrija i obrazovanje. Andragoški glasnik, str. 37-48.

Nuroğlu, E., \& Dreca, N. (2011). Analyzing bilateral trade flows of Bosnia and Herzegovina. Journal of Business and Economics, 30-50.

Obadić, A. (2001). Značaj industrije za gospodarski razvitak. Hrčak Srce, 52 No. 9-10, 1100-1112.

Pharoskc. HDI. Retrieved 15. 042021 iz https://hr.pharoskc.com/876-what-is-the-human-developmentindex-hdi.

Ristić, K., Komazec, S., \& Ristić, Ž. (2015). Makroekonomija. Beograd: EtnoStil.

Rodrik, D. (2009). Growth after the crisis. Cambridge: Harvard Kennedy School.

Szirmai, A. (2012). Industrialisation as an engine of growth in developing countries, 1950-2005. Structural Change and Economic Dynamics, 12(4), 406-420.

United Nations Industrial Development Organization (2014). Manufacturing as an engine of growth: Which is the best fuel? Vieena: UNIDO.

World Bank (2021). World Bank. Retrieved 12 February 2021 from World Bank: https://data.worldbank.org/indicator/NV.IND.MANF.ZS. 
E. Cero \& M. Mustafić - Impact of Manufacturing Industry Performance on Economic Growth ... 